\begin{tabular}{|l|l|l||}
\hline \multicolumn{2}{|c|}{ PublisherInfo } \\
\hline \hline PublisherName & $:$ & BioMed Central \\
\hline \hline PublisherLocation & $:$ & London \\
\hline \hline PublisherImprintName & $:$ & BioMed Central \\
\hline \hline
\end{tabular}

\title{
Resistance to vCJD
}

\begin{tabular}{|l|l|l||}
\hline \multicolumn{2}{|c|}{ ArticleInfo } \\
\hline \hline ArticleID & $:$ & 4255 \\
\hline \hline ArticleDOI & $:$ & $10.1186 /$ gb-spotlight-20011119-01 \\
\hline \hline ArticleCitationID & $:$ & spotlight-20011119-01 \\
\hline \hline ArticleSequenceNumber & $:$ & 326 \\
\hline \hline ArticleCategory & $:$ & Research news \\
\hline \hline ArticleFirstPage & $:$ & 1 \\
\hline \hline ArticleLastPage & $:$ & 2 \\
\hline \hline & $:$ & RegistrationDate : 2001-11-19 \\
ArticleHistory & $:$ & OnlineDate \\
\hline \hline ArticleCopyright & $:$ & BioMed Central Ltd2001 \\
\hline \hline ArticleGrants & $:$ & \\
\hline \hline ArticleContext & $:$ & 130592211 \\
\hline \hline
\end{tabular}




\section{Jonathan B Weitzman}

Email: jonathanweitzman@hotmail.com

The Variant Creutzfeldt-Jakob disease (vCJD) is a much-publicized prion disease that is linked to infection with BSE (bovine spongiform encephalopathy) prions and is distinct from sporadic or inherited CJD forms. In the November 15 Nature, Jackson et al. report that resistance to vCJD is associated with a particular human leukocyte antigen (HLA) type (Nature 2001, 414:269-270). They compared the HLA types of vCJD sufferers, sporadic CJD patients and unaffected individuals; they typed 50 British vCJD patients and found a significant reduction in the frequency of the DQB $1 * 0301 / 4 / 9$ allele (called DQ7): $12 \%$ in vCJD compared to $46 \%$ in the sporadic CJD group and $36 \%$ in the normal population. The authors conclude that the presence of DQ7 protects against $\mathrm{VCJD}$, with a relative risk factor for negative individuals of 3.3. The mechanism by which this variant of the major histocompatibility class II molecule could affect prion infection and development of the disease is unclear. If these results can be confirmed with a much larger sample group, then HLA-DQ typing could be useful in vCJD diagnosis and in the identification of high-risk groups.

\section{References}

1. Variant Creutzfeldt-Jakob disease.

2. Nature, [http://www.nature.com] 